\title{
Expected palaeoanthropological and archaeological signal from a Neolithic demographic transition on a worldwide scale
}

\author{
Jean-Pierre P. Bocquet-Appel1 and Jérôme Dubouloz² \\ 1 CNRS, EP 214744 Paris, France \\ bocquet-appel@ivry.cnrs.fr \\ 2 CNRS, UMR 7041, "Protohistoire Européenne", Nanterre, France
}

\begin{abstract}
A signal of major demographic change was detected from a palaeoanthropological database of 68 Meso-Neolithic cemeteries in Europe (reduced to 36 due to a sampling bias). The signal is characterized by a relatively abrupt change in the proportion of immature skeletons (aged 5-19 years), relative to all buried skeletons (5 years + ). From the Meso to the Neolithic, the proportion rose from approximately $20 \%$ to $30 \%$. This change reflects a noticeable increase in the birth rate over a duration of about 500-700 years, and is referred to as the Neolithic Demographic Transition (NDT). Another category of independent archaeological data, on enclosures $(N=694)$, which are interpreted as a response to population growth within the social area, reveals a similar signal at the same tempo. If this is a true signal, we should expect it to be detected also in all the independent centres of agricultural invention worldwide. The NDT is at the historical root of the pre-industrial populations that would gradually spread across the Earth and which are now rapidly disappearing.
\end{abstract}

IZVLEČEK - Na osnovi paleoantropološke baze podatkov iz 68 evropskih mezo-neolitskih grobišč (zaradi pristranskih vzorcev zmanjšanih na 36) smo ugotovili večjo demografsko spremembo, za katero je značilna razmeroma nenadna sprememba deleža nerazvitih skeletov (starost 5 do 19 let) glede na vse pokopane skelete (5 let in več). Od mezolitika do neolitika to razmerje naraste od okoli $20 \%$ na 30\%. Ta sprememba kaže na znaten porast deleža rojstev v obdobju 500 do 700 let in se nanaša na neolitski demografski prehod. Druga skupina neodvisnih, zaključenih arheoloških podatkov $(N=694)$ iz socialnega okolja, ki jih razlagamo kot odgovor na rast prebivalstva, kaže podobno spremembo v enakem tempu. Ce je znak za spremembo pravilen, lahko pričakujemo, da ga bodo zaznali v vseh neodvisnih središčih začetka kmetovanja po svetu. Neolitski demografski prehod je zgodovinski začetek predindustrijske populacije, ki se je postopoma razširila po Zemlji in ki danes hitro izginja.

KEY WORDS - Neolithic; demographic transition; cemeteries distribution; enclosures distribution

\section{INTRODUCTION}

The impact of the demographic change generated by the Meso-Neolithic transition on a European scale is mainly evident in the very significant increase in archaeological remains, but the pace of this change and its magnitude have not really been measured: was it, on average, slow or rapid? Did this major transformation in a way of life correspond to a relatively abrupt demographic change, with a significant increase in the number of humans, i.e. in the language of demographers, to a demographic transition? Or should we be considering rather slow growth, with no sign of any kind of demographic revolution?

A Neolithic demographic transition (NDT) can be detected through at least two types of data: palaeo-anthropological and archaeological. The first are represented by the distribution of skeletons by age in cemeteries. These distributions allow the generating demographic parameters to be directly inferred via the demographic theory of stable population (dating 
back to Lotka 1928; see Bourgeois-Pichat 1994, for a presentation). The archaeological data can also account for the change through variations in their density (quantity of information per geographical or temporal unit); assuming a roughly linear relationship between demographic density and archaeological density, we can indeed expect to see significant population growth producing a corresponding increase in archaeological information, and vice-versa: where remains are numerous, the population must also have been large; an archaeological desert means that there was nobody. The question thus arises as to which unit of archaeological information is relevant as a reflection of demographic change. The genetic data will be omitted here. Recent validations of contradictory genetic models that are taken into account for the distribution of markers in Europe some of which indicate a Neolithic population movement originating in the Middle East (for a summary, see Cavalli-Sforza 1997), others a Palaeolithic movement originating in a Pyrenean refuge zone (Torroni et al. 2001; Forster et al. 2001) - leave the attentive observer in some doubt as to the chronological resolution of scenarios that can be tested against genetic data over periods of less than 50000 years.

Palaeoanthropological data from cemeteries are still the best candidates for detecting demographic change. They make it possible to obtain a simple non-conventional demographic indicator on the distribution of skeletons by age, the information being represented by the proportion of immature individuals aged 5 to 19 years in cemeteries. In a growing population, the proportion of immature individuals (living or dead) is high; in a declining population, the proportion is low. Besides the palaeoanthropological data, we also looked for an independent archaeological marker. This is represented by enclosures. During a period when significant demographic growth occurred, a corresponding increase can be assumed in the number of constructions for collective use, such as places of worship, military establishments, cemeteries, markets, mills, etc. An NDT signal was detected from a palaeoanthropologic database of Mesolithic and Neolithic cemeteries, representing a space-time sample of this proportion on the scale of Europe (Bocquet-Appel 2002; Bocquet-Appel and Paz de Miguel Ibanez 2002). The questions that arise are: is the change detected from the palaeoanthropologic data echoed by the number of enclosures and enclosure systems? Do these two data categories, palaeoanthropological and archaeological, point in the same direction to represent the pace and range of a Meso-Neolithic demographic change, or do they show discordances, bringing the assumption of an NDT into doubt? If the NDT hypothesis is accepted, what was its pattern, i.e. in which direction was the variation in mortality and birth rates? What was its magnitude in terms of growth rate? What were its predictable epidemiological consequences and its long-term demographic implications on a worldwide scale?

\section{PALAEOANTHROPOLOGICAL DATA FROM CEME-} TERIES AND THEIR DEMOGRAPHIC SIGNIFICANCE

After exhaustive research in the literature, these data have been represented by a non-conventional demographic indicator, which is the proportion $P$ of immature skeletons aged 5 to 19 years, $d(5-19)$, relative to the total number of skeletons in a cemetery, $d\left(5^{+}\right)$, minus children aged under 5 years, which are known to be under-represented:

$$
{ }_{15} \mathrm{P}_{5}=\mathrm{d}(5-19) / \mathrm{d}\left(5^{+}\right) ;
$$

the demographic notation ${ }_{15} \mathrm{P}_{5}$ means the proportion of skeletons aged 5 years, to 5 years plus 15 years, i.e. 5 to 19 years. The criteria for the archaeological and anthropological selection of cemeteries and the corresponding enumerations and calculations are detailed in Bocquet-Appel (2002). The data represent 68 Meso-Neolithic cemeteries (Fig. 1). The dates (calibrated) of the cemeteries were either those given in the original publications, or the average dates of the cultures (or horizons) of these cemeteries. The demographic interpretation of ${ }_{15} \mathrm{P}_{5}$ is obtained from a reference sample of 45 preindustrial lifetables, from which demographic parameters were regressed on simulated stable populations, called palaeodemographic estimators (Bocquet-Appel 2002; Bocquet-Appel and Masset 1996; Bocquet and Masset 1977). As an example, Figure 2 represents the relationship of ${ }_{15} \mathrm{P}_{5}$, with the crude birth rate $(b)$ and life expectancy at birth $\left(e_{0}\right)$. The relationship holds good with the input variable in the population represented by $b$, but becomes null with the output variable represented by $e_{0}$.

\section{ARCHAEOLOGICAL DATA}

These are represented by approximately 700 enclosures in Central and Western Europe listed by Andersen (1997), to which a few units were added. Their significance as palaeodemographic markers is discussed in Bocquet-Appel and Dubouloz (2003). The Neolithic enclosures are interpreted as having a struc- 


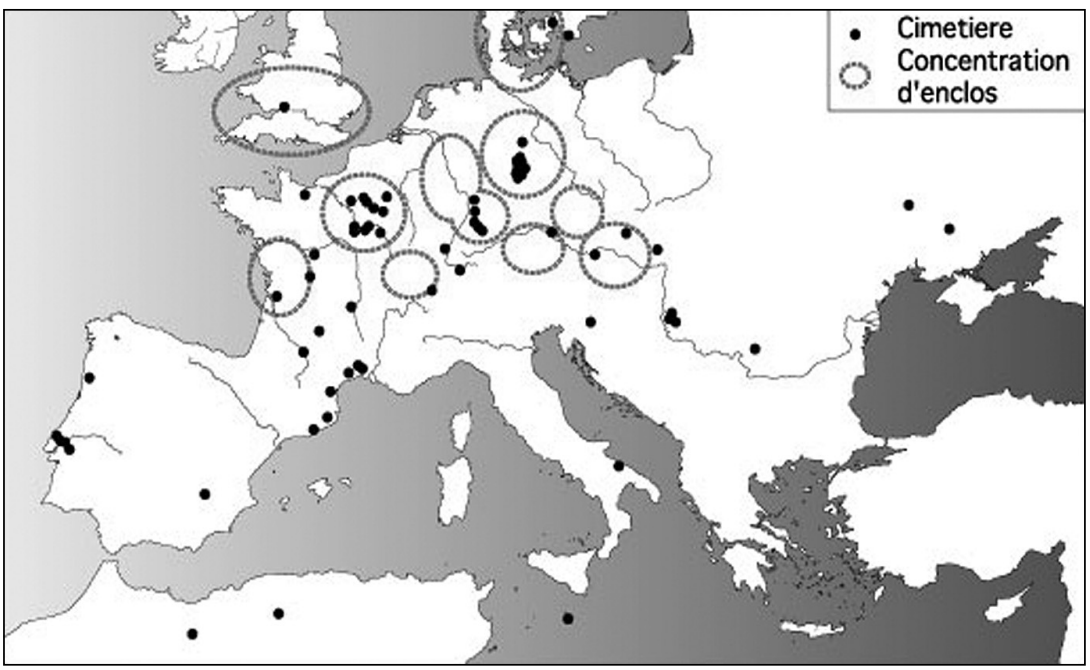

Fig. 1. Geographical distribution of 68 Meso-Neolithic cemeteries (black points) and of 694 enclosures (circles dotted lines) (from Bocquet-Appel and Dubouloz 2003).

tural link with the processes underlying the organization of social space in prehistoric communities. A common general significance, which seems to include particular cases, is that each one, at its own level (from local to regional) can be seen, as a territorial marker that polarizes the geographical and social space through a "monumental" signal of supradomestic value. A connection is therefore likely between demography and sites of this type. This connection is taken as reflecting a form of demographic pressure. To minimize documentary risks stemming from differences in national archaeological practices, the geographical space analyzed is roughly copied from that of the "Danubian Neolithic colonization". The selected sites thus relate to the regions which, to the north of the Alpine arc, stretch from Transdanubia to the Atlantic and the Baltic (Fig. 1). An archaeological chronology, broadly dated by ${ }^{14} \mathrm{C}$ measurements, was used.

\section{THE RELATIVE CHRONOLOGICAL RE-} FERENCE FRAME OF THE CHANGE

The distribution of data in space and time accumulates processes in the Meso-Neolithic transition which occurred at different times from locality to locality on the map, and this makes it difficult to bring out the phenomenon of a single demographic transition that transcends absolute chronology and proceeds at its own pace. Instead of an absolute chronology, the reference frame was changed, and the data positioned within a relative chro- nology. The reason for this change of reference frame is to concentrate archaeological information that is relatively scarce and scattered over space and time into the same reference frame provided by a relative chronology, in order to bring out an overall pattern underlying the data. Assuming that the Neolithic demographic transition was a demographic process in itself, occurring independently of the geographical location and absolute date of the sampled sites (cemeteries), as did the contemporary demographic transition, then geography can be eliminated from the space-time distribution of data, to preserve only the time distribution with reference to the local date when the process began, which is called the 'neolithisation front'. A profile common to all the data was thus obtained, with no influence from geography or absolute chronology. The chronological distance of a cemetery to the neolithisation front, both localized in $\mathrm{X}$, is thus the duration $d t$ separating the dating of the front, $t_{0}(X)$, from that of the cemetery, $t(X)$, that is to say: $\operatorname{dt}(X)$ $=t_{0}(X)-t(X)=d t$. When dt is negative, the site is chronologically located before the neolithisation front, i.e. in the Mesolithic (see Bocquet-Appel 2002).

To help understand the nature of the change in the chronological reference frame, additional explana-

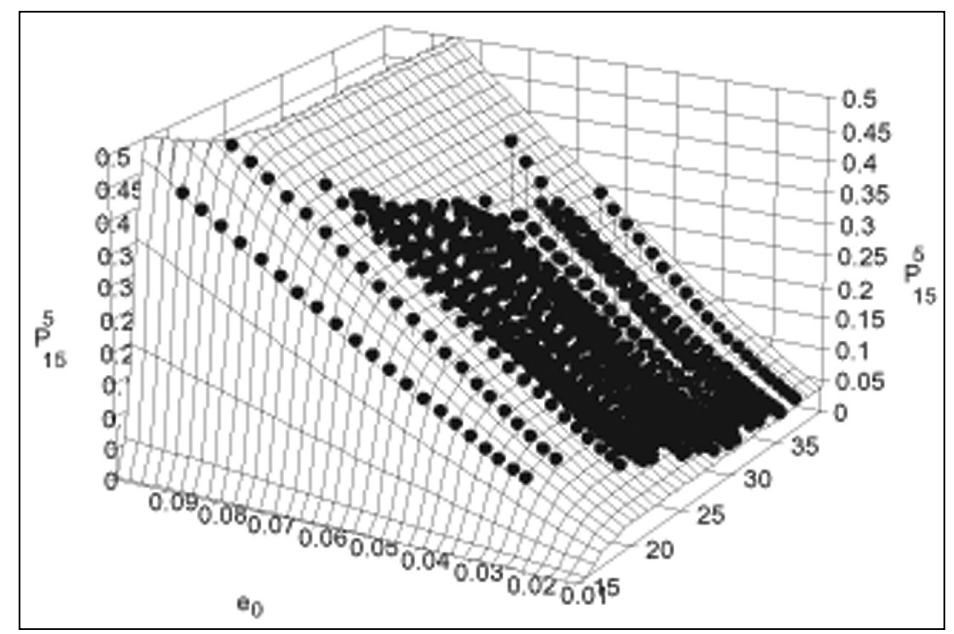

Fig. 2. Relationship of ${ }_{15} P_{5}$, with the crude birth rate (b) and the life expectancy at birth $\left(e_{0}\right)$. The relationship is good with the input variable in the population represented by but nil with the output variable represented by $e_{0}$. 
tions are given here, based on an historical example. It should be remembered that the contemporary demographic transition, featuring a historical drop in mortality and then in fertility, is a process taking place on a worldwide scale, but at different dates, in a chronological window extending from the $18^{\text {th }}$ to the $21^{\text {st }}$ centuries. For example, this transition started at around 1841 in Privas (France), 1901 in Carlow (Ireland) and 1961 in Coimbatore (India) (Balabdaoui et al. 2001; Bocquet-Appel and Jakobi 1996; 1998). In order to compare regional demographic changes regardless of the chronological time lag, for example to assess their pace or their amplitude relatively to each other, all the profiles representing the temporal change should be placed within the same neutral reference frame of a relative chronology. Within this framework, the natural reference point is the date when the transition process began in each region (respectively 1841, 1901 and 1961), which is taken as time $t=0$. A relative chronology common to the three regions can thus be established by simply subtracting their respective starting dates from each of the three absolute chronologies. The resulting chronology is in units of deviation from the start of the process. It is actually a time span, but with no reference to an absolute chronology. This unit of deviation, may be called dt. Figure $3 a$ shows the reduction in the average number of children, via the Total Fertility Rate (TFR) in the three regions of our example, through the relative chronology dt. The pace of the fertility transition is much faster in Coimbatore (India) than in Privas (France), although it occurred 120 years later. When the deviations, $\mathrm{dt}$, are plotted on a graph, the range of chronological variation for the demogra- phic transition, considered as a global phenomenon occurring independently of time or place, becomes apparent (see Fig. 3b). The representation of the demographic change is quite correct, whereas it is wrong if it is represented in terms of absolute chronology (Fig. 3c).

\section{DATA ANALYSIS}

A trend emerging from cemeteries and detection of the signal of a demographic transition

Figure 4 shows the ${ }_{15} \mathrm{P}_{5}$ profile obtained at a chronological distance from the neolithisation front $\mathrm{dt}$, from the total database $\left(\mathrm{U}=6, \chi^{2}=20.450\right.$ with 1 df, $\mathrm{P}<0.000)$. A transition signal is detected. This profile shows the trend underlying the ${ }_{15} \mathrm{P}_{5}$ in the relative chronology framework. It is estimated by a local fit in the ${ }_{15} \mathrm{P}_{5}$ cloud, which is comparable to a moving average (also called a Loess fit; BocquetAppel 2002). The test for rejecting the null hypothesis of a flat profile, i.e. not showing the broken line typical of an abrupt change occurring in a transition, was performed with Mann-Whitney's non-parametric $\mathrm{U}$ test. This test constitutes the detection of the signal of a demographic transition. Finally, to estimate the values of the demographic variables, palaeodemographic estimators were applied directly to the values of the profile of the ${ }_{15} \mathrm{P}_{5}$, not to the individual values for cemeteries. Although the profile (Fig. 4) is interesting, a bias from the over-representation of immature individuals in small cemeteries, probably of archaeological origin, was detected, forcing us to eliminate cemeteries where the sample

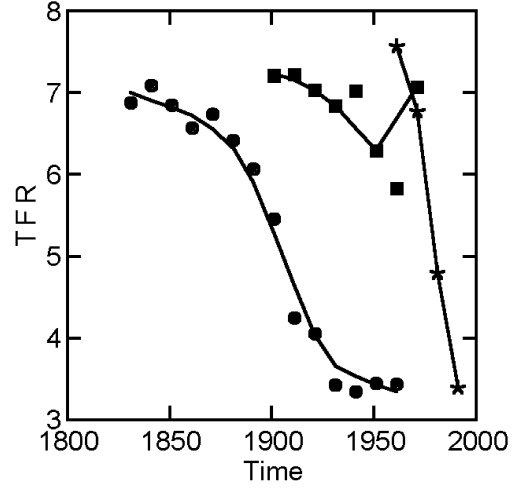

A

$$
\begin{aligned}
& \text { - Privas (France) } \\
& \text { - Carlow (UK) } \\
& \text { * Coimbatore (India) }
\end{aligned}
$$

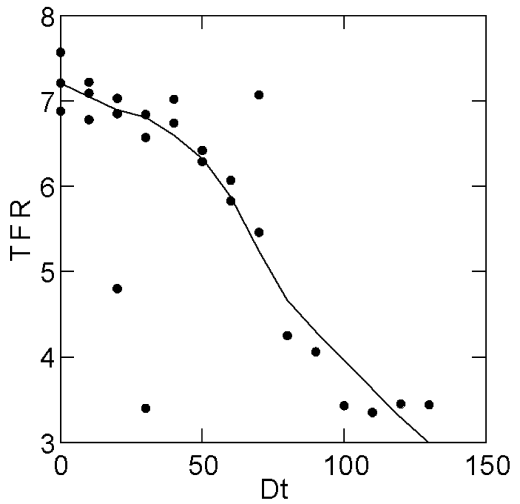

B

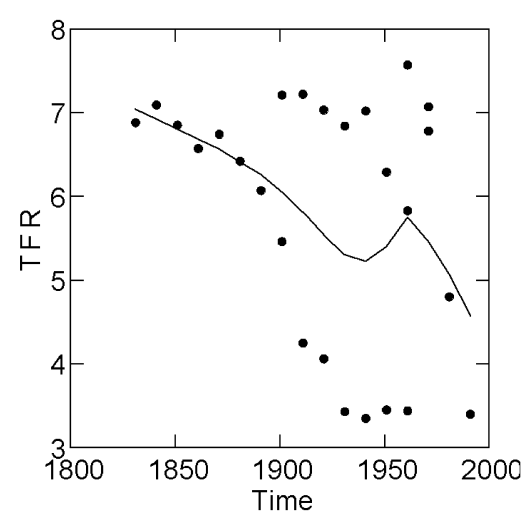

C

Fig. 3. Fertility transition (TFR) in three regions. The onsets are respectively in 1830 (Privas, France), 1911 (Carlow, Ireland) and 1961 (Coimbatore, India). A) Each transition in absolute chronology; B) The average (loess fit) of the three transitions in relative chronology (dt); C) the average (loess fit) of the three transitions in absolute chronology. The pattern of the fertility transition is detected in relative (dt) but not in absolute chronology. 


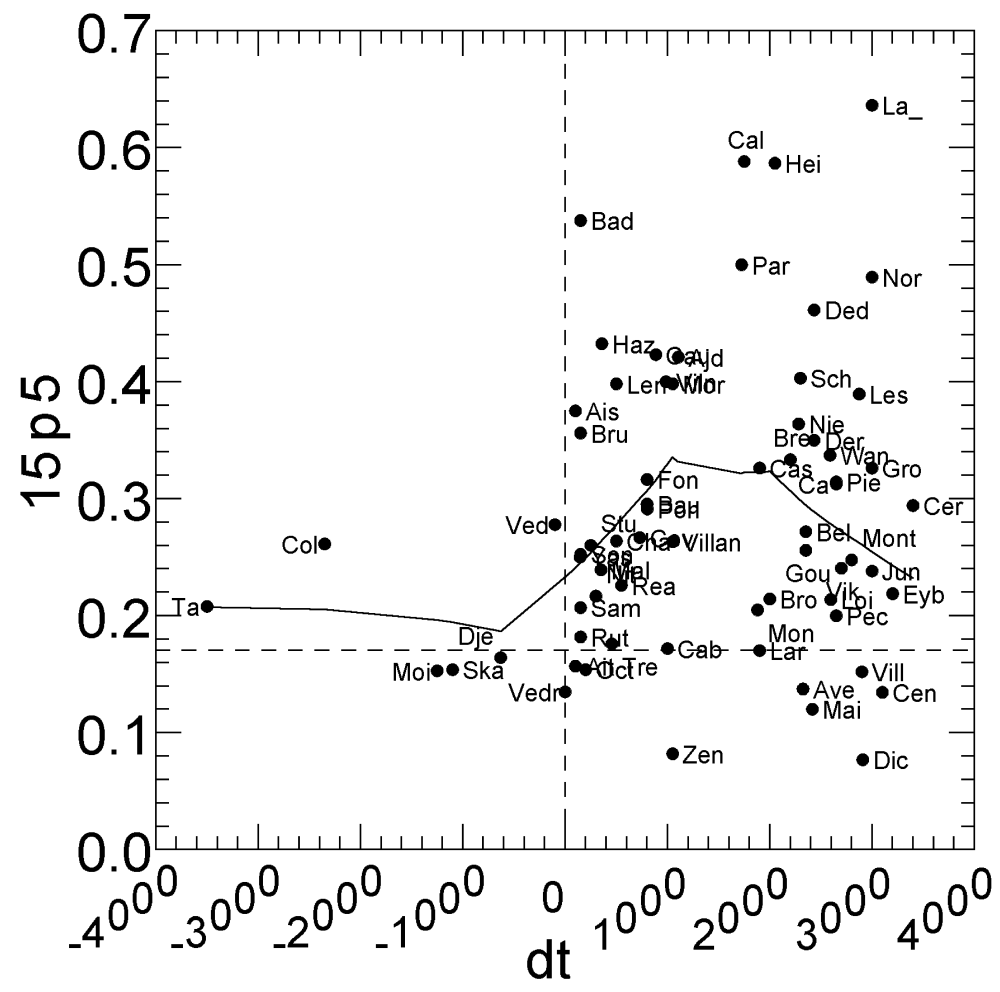

Fig. 4. Profile proportion of immature ${ }_{15} P_{5}(P(5-19))$ in the cemeteries (vertical axis) with the chronological distance to the neolithisation front (dt, horizontal axis). $N=68$ Mesolithic and Neolithic sites. Note: $d t=0$ is the starting chronological point of the neolithisation front, $d t<0$ is in the Mesolithic, $d t>0$ is in the Neolithic. Up to a constant, the profile represents the variation of the birth rate. It shows a continuous increase which begins around $\boldsymbol{d t}=-200$ years until dt $=1000$ years (from Bocquet-Appel 2002). very substantial change in the proportion of immature skeletons lasts almost throughout the entire Neolithic dt, relative to the Mesolithic. In short, the palaeoanthropological data from the cemeteries contain demographic information which, taken overall, reveal the pattern of a true Meso-Neolithic transition in Europe. With currently available data, a clear break from the previous stationary demographic regime of hunter-gatherers characterises this transition, over a relatively short time span of $\mathrm{dt}$ $\cong 500$ years.

The trend in the enclosure data

Two approaches were used, the first based on absolute chronology, i.e. historical time, the second on relative, i.e. more local chronology, dt, in order to bring the results closer to those obtained with the palaeoanthropological data from cemeteries. Only the latter approach is described here (see Bocquet-Appel and Dubouloz 2003). The profile of enclosure frequencies (count) along the chronological distance $\mathrm{dt}$ is represen- size of skeletons was below 50 (Bocquet-Appel 2002). The new, reduced sample thus includes only 36 cemeteries (3 Mesolithic, 33 Neolithic). This narrows the chronological frame from $\mathrm{dt}=-1.500$ to $\mathrm{dt}=3.000$. Figure 5 shows the variation in estimated crude birth rate, with at profile of ${ }_{15} \mathrm{P}_{5}$ with $\mathrm{dt}$, obtained from these 36 cemeteries. A signal of major demographic change, starting at the very beginning of the Neolithic $\left(U=26, \chi^{2}=11.04\right.$ with $1 \mathrm{df}$, $\mathrm{P}=0.001)$, was thus detected. Our interest here is only in the zone on the neolithisation front. This is of particular interest as it provides information on the magnitude of the change at its onset. If we consider the maximum of the first bulge on the $d t$ axis as representing the upper limit of the Neolithic demographic transition, at its onset, then the transition covers a relatively short time of approximately 500 years. On the profile, from $\mathrm{dt}=0$ to the maximum of the first bulge ( $\mathrm{dt} \cong 500)$, the smoothed value corresponding to the proportion of immature individuals relative to $\mathrm{d}\left(5^{+}\right),{ }_{15} \mathrm{P}_{5}$, rises from $16 \%$ to $27 \%$, i.e. a $70 \%$, increase, while the corresponding estimated value of the growth rate rises from $-0.3 \%$ to $1.3 \%( \pm 1.07 \%)$ (see Bocquet-Appel 2002). This ted in Figure 6 (black line). This shows a rapid increase in the size of the enclosure sites, as from $\mathrm{dt}=$ 300-600 years, culminating at $\mathrm{dt}=600-900$ years, then a slow decrease until $\mathrm{dt}=1200-1500$ years, followed by a clear decline. The data were then sorted against the criterion of whether they were included in the distribution area of the Linear Ceramics Culture (LBK). The profile for LBK regions (dotted line) shows a rapid response at $\mathrm{dt}=300-900$ years; a recrudescence in the number of enclosures occurs at $\mathrm{dt}=1800-2400$ years after the beginnings of the Neolithic, measured locally, mainly from eastern Germany to Bavaria. The profile for the periphery shows two peaks close together, separated by a threshold located at a high level: the first of these peaks (where $\mathrm{dt}=300-600$ years) relates to the areas of the northern periphery (Denmark, Great Britain), the intermediate threshold (where $\mathrm{dt}=$ $600-1200$ years) points to the north of France and the second peak (where $\mathrm{dt}=1200-1500$ years) represents the west of France. The extreme western periphery thus indicates a long time-lag, which can even be considered to broaden downstream (enclosures at the end of the $4^{\text {th }}$ and the beginning of the 
$3^{\text {rd }}$ millennium in the west of France). This profile for peripheral enclosures (dotted line) thus suggests three different growth processes: a rapid response, as in the LBK regions in Denmark and England, a slow response in the west of France; and a moderate response in the north of France. The broad outline of the main profile (black line) and the fairly rapid "response" time after the "local" beginnings of the Neolithic that it suggests, correlate well with the demographic phenomenon deduced from the cemeteries (Figs. 4 and 5). This general distribution of territorial markers, in relative time, particularly in the LBK areas in Denmark and in England, suggests a rapid response from a strongly stimulated system, followed by its adaptation to the new situation.

\section{DISCUSSION AND CONCLUDING REMARKS}

In theory, what connects the variation of the two indicators (palaeoanthropological, representing the proportion of immature ${ }_{15} \mathrm{P}_{5}$, and archaeological, representing the number of enclosures), is the growth of population with the establishment of an agro-pastoral way of life. Their two profiles should, therefore, be similar. Figures 5 and 6 show that this is indeed the case. The two indicators also converge in the es-

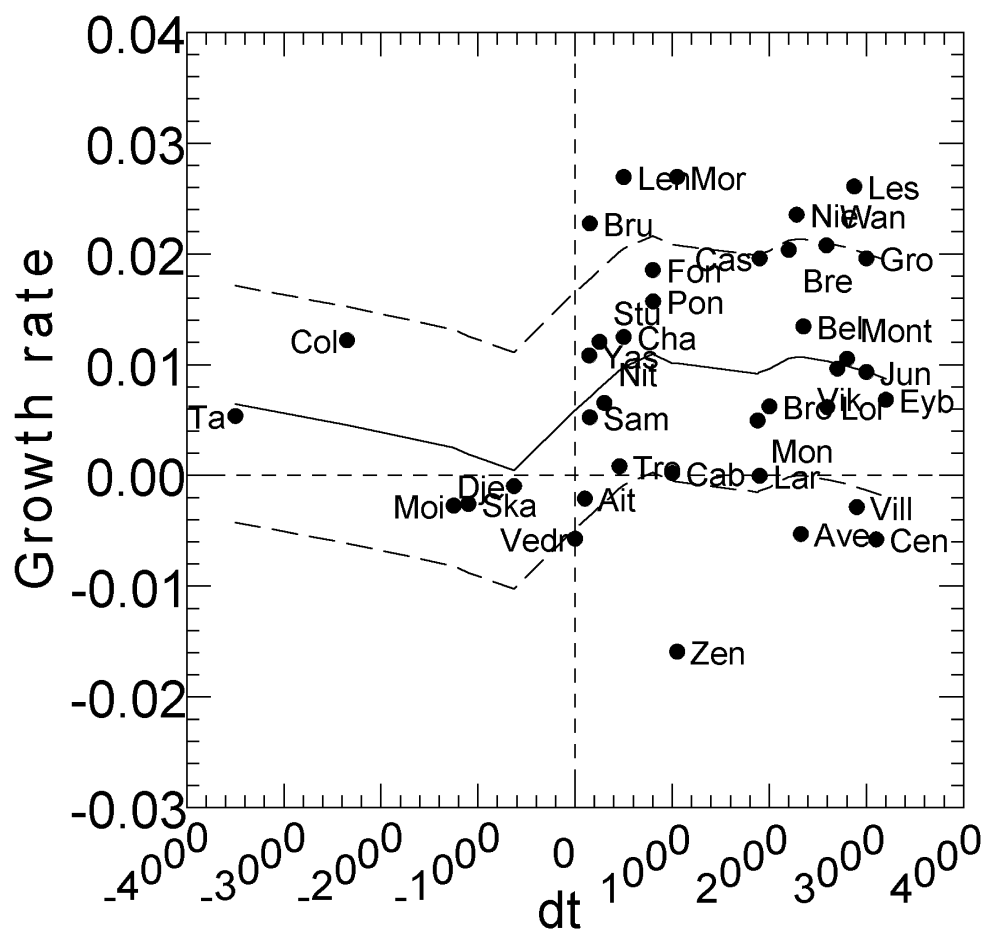

Fig. 5. Variation of estimated crude birth rate on the profile of ${ }_{15} P_{5}$ with $\mathrm{dt}$, obtained from the reduced sample of 36 cemeteries. The signal of an important demographic change is detected, which started at the onset of the Neolithic $\left(U=26.5, \chi^{2}=11.04\right.$ with $1 \mathrm{df}$, $P=0.001$ ) timation of the pace at which this first demographic transition in Europe, considered overall, emerged. The pace was fastest for the palaeoanthropological data $(\mathrm{dt} \cong 500)$ as for enclosure data $(\mathrm{dt}=600-900)$. In other words, the demographic change that generated a noticeable growth in the population became established over a relatively short time span. This change is characterized by a clear break with the former stationary regime of Mesolithic hunter-gatherers (according to the palaeoanthropological data), over a time span of approximately 500-900 years, possibly less. The likely cause of the rising birth rate and underlying fertility rate is to be found in the shorter birth interval that ensued from the sedentarisation of farming communities (Bocquet-Appel 2002).

But, as we know, any growing population will eventually reach the limits of its carrying capacity, triggering off the mechanisms of the Malthusian model (for a summary, see Wood 1998; Lee 1994). The probable scenario is therefore as follows: after a rise in the crude birth rate, a corresponding increase in the crude death rate is to be expected, i.e. a return to homeostatic equilibrium. For the NDT, the rise in mortality must have been caused by the emergence of new pathogens, mainly infectious diseases resulting from the zoonoses of domesticated animals (cattle, sheep, goats and pigs), as well as from the anastomosis of village units that facilitated their spreads (BocquetAppel 2002). Mortality, which has a major impact on population, primarily affects children under 5 years old. A history of infectious diseases and their phyletic relationship with pathogenic animals is yet to be written (see also Gubser and Smith 2002; McNeill 1993; McKeown 1988). However, candidates would include viral diseases (smallpox, measles, mumps, rubella, chicken pox and poliomyelitis) and bacterial diseases (whooping-cough, diphteria, meningitis and typhoid). We now need to seek genetic markers of these candidate diseases, in the pulp cavities of the teeth of child skeletons, following the method that was successfully used for plague (Drancourt et al. 1998). We need to attempt a dating for the initial appearance of these infectious diseases, at the end of the Mesolithic era and the beginning of the Neolithic (for example with the PPNA vs. PPNB locally), in 


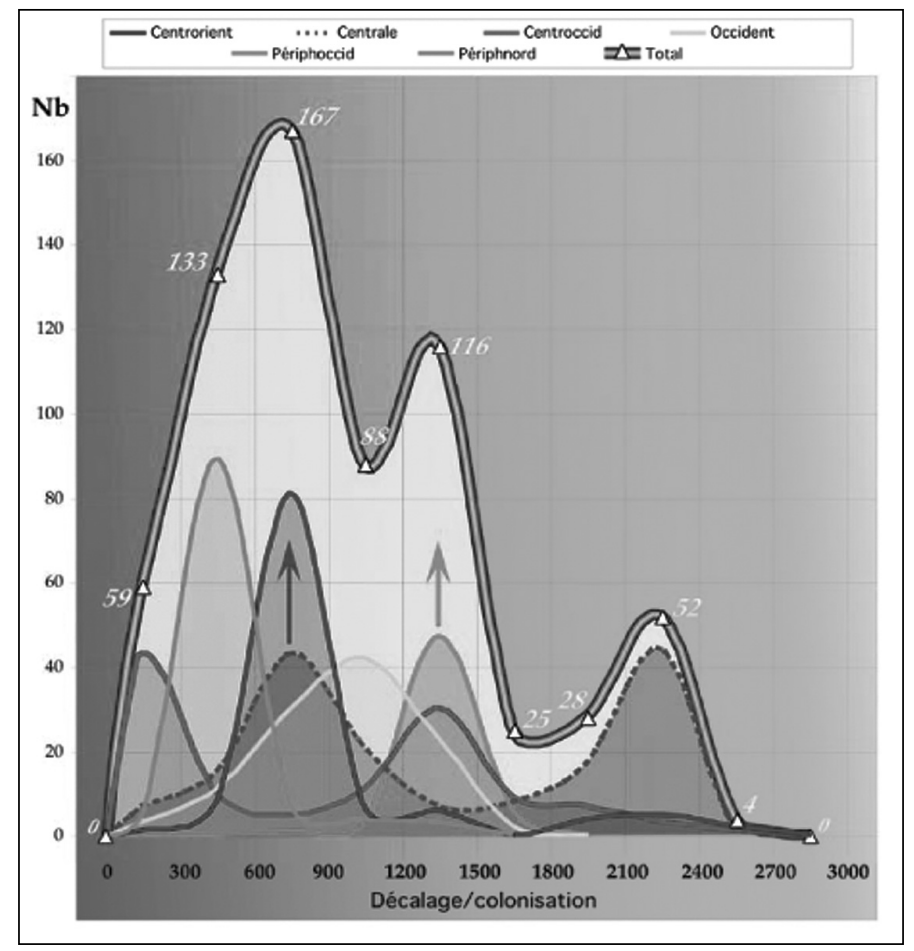

Fig. 6. Profile of the number of enclosure at the chronological distance dt (black line). It shows a fast growth of the number of enclosures as of $d t=300-600$ years, to culminate with $d t=600-900$ years, then a slow decrease until $d t=1200-1500$ years before a marked depression (from Bocquet-Appel and Dubouloz 2003).

order to try to estimate the duration of the demographic expansion which preceded the return to homeostatic equilibrium.

The consequences of the NDT were perhaps comparable with that of the natural demographic transition in $19^{\text {th }}$ century Europe, in terms of rapid demographic expansion. A consequence of the contemporary demographic transition has been an explosive growth rate of about $3 \%$ over a hundred years. What followed was the continent-wide destruction of the hunter-gatherers and horticulturists of North America and Australia, resulting from a major demographic invasion by surplus populations of European peasants. But the order of the causal demographic variables and their directions were reversed: rising fertility followed by rising mortality during the NDT, as against falling mortality followed by a drop in fertility during the contemporary Western demographic transition.

The detection of the NDT signal was conditioned by the space-time data available. The demographic pattern obtained is a kind of average of samples that centred in particular on the "Danubian" culture. The NDT we detected did not necessarily occur at the same pace everywhere on the map, especially around the periphery of Europe. A geographical differentiation of the process needs to be considered, depending on the local pace of neolithisation. More data, with a better distribution over time and space, should help to refine the regional picture of the NDT.

Finally, the assumption can now be made that the NDT occurred in all the independent centres of agriculture invention on Earth, during the chronological window from 10000 to $4000 \mathrm{BP}$. Its signal should therefore be detectable in cemetery data from the regions corresponding to these centres. As the geographical expansion of the agro-pastoral economic system, the vehicle for the new demographic regime, extended from these centres, the areas eventually connected to form a single area of relative demographic homogeneity, giving rise to the worldwide pre-industrial population regime, featuring a low growth rate

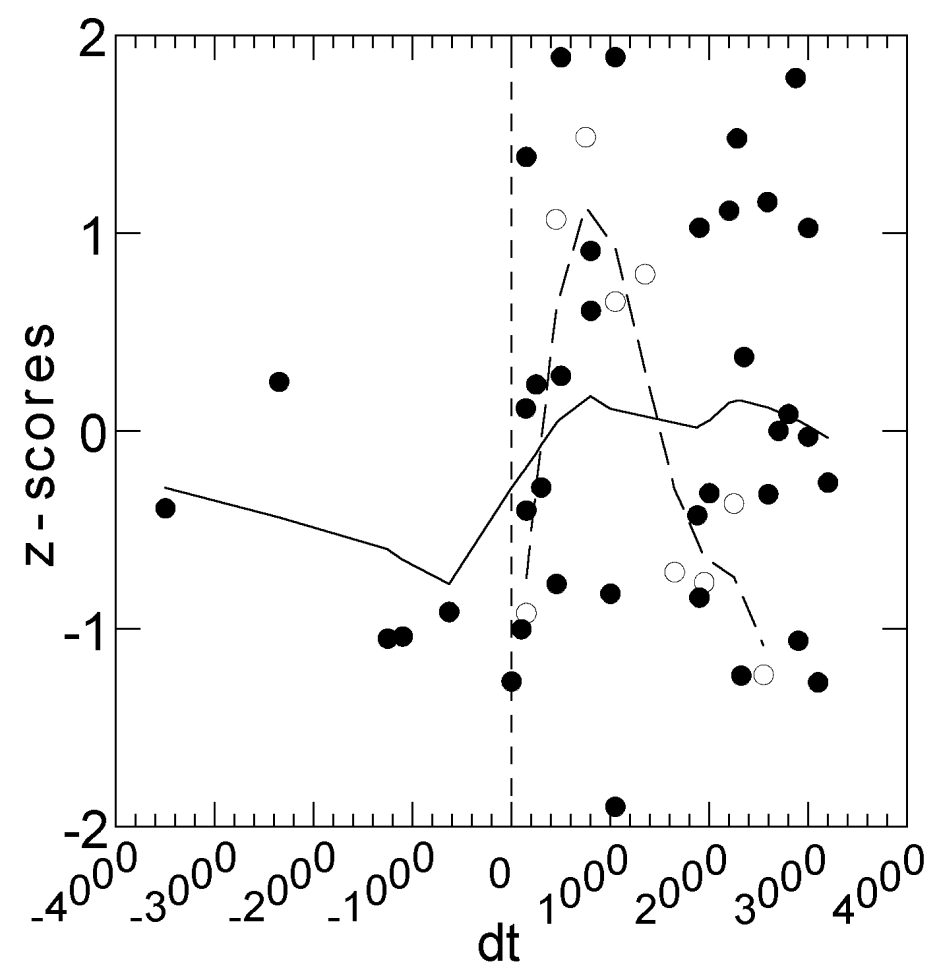

Fig. 7. Projection of the two standardized profiles (zscores, vertical axis), palaeoanthropological (cemeteries) and archaeological (enclosures) with the chronological distance to the neolithisation front (dt, horizontal axis). 
and high mortality and birth rates, also called the "high pressure system" (McCaa 2002). The relic demographic regime of the hunter-gatherers known to ethnography has remained at its margins. With the expansion of the contemporary demographic transition, this pre-industrial population regime, which dates back to the Neolithic, is now disappearing.

\section{REFERENCES}

ANDERSEN N. H. 1997. The sarup enclosures. Jutland Archaeological Society. Moesgaard, Aarhus University Press, Aarhus.

BALABDAOUI F., BOCQUET-APPEL J. P., LAJAUNIE C. and IRUDAYAN RAJAN S. 2001. Space-time evolution of fertility transition in India (1961-91). International Journal of Population Geography7: 129-148.

BOCQUET-APPEL J. P. 2002. The Palaeoanthropological traces of Neolithic Demographic Transition. Current Anthropology 43: 638-650.

BOCQUET-APPEL J. P. and DUBOULOZ J. 2003. Les traces paléoanthropologiques et archéologiques d'une transition démographique néolithique en Europe. Bulletin de la Société Préhistorique Française 100 (4): 699-714.

BOCQUET-APPEL J. P. and MASSET C. 1996. Palaeodemography: Expectancy and false Hope. American Journal of Physical Anthropology 99: 571-583.

BOCQUET-APPEL J. P. and JAKOBI L. 1998. Evidence for a spatial diffusion of contraception at the onset of fertility transition in Victorian Britain. Population, An English Selection, special issue New advances in Social Sciences 10, 1: 181-204.

BOCQUET J. P., MASSET C. 1977. Estimateurs en Paléodémographie. L'Homme, XVIII: 65-90.

BOCQUET-APPEL J. P. and PÃZ DE MIGUEL IBANEZ M. 2002. Demografia de la difusion neolitica en Europa y los datos palaeoanthropologicos. Sagutum 5: 23-44.

BOURGEOIS-PICHAT J. 1994. La dynamique des populations. Populations stables, semi-stables et quasistables. Institut National d'Etudes Démographiques, Travaux et Documents Cahier No. 133, Paris.
CAVALLI-SFORZA L. L. 1997. Genetic and cultural diversity in Europe. Journal of Anthropological Research 53: 383-404.

DE SOUZA LEAL E., DE ANDRADE ZANOTTO P. M. 2000. Viral diseases and human evolution. Memórias do Instituto Oswaldo Cruz 95(1): 193-200.

DRANCOURT M., ABDOUDHARAM G., SIGNOLI M., DUTOUR 0., RAOULT D. 1998. Detection of 400 year old Yersinia pestis DNA in human dental pulp: an approach to the diagnosis of ancient septicaemia. Proceedings of the National Academy of Sciences USA 19: $12637-40$.

FORSTER P., TORRONI A., RENFREW C., RÖHL A. 2001. Phylogenetic star contraction applied to Asian and Papuan mtDNA evolution. Molecular Biology and Evolution 18:1864-1881.

GUBSER C. and SMITH G. L. 2002. The sequence of camelpox virus shows it is most closely related to variola virus, the cause of smallpox. Journal of $\mathrm{Ge}$ neral Virology 83(4): 855-872.

LEE R. 1994. Human fertility and population equilibrium. In: Human reproductive ecology: interactions of environment, fertility, and behavior. In K. L. Campbell and James W. Wood (eds.), Annals of the New York Academy of Sciences 709: 396-407.

MCCAA R. 2002. Palaeodemography of the Americas. From ancient time to colonialism and beyond. The Backbone of history. In R. H. Steckel and J. C. Rose (eds), Cambridge University Press: Cambridge: 94-124.

MCKEOWN T. 1988. The origin of human diseases. Blackwell Publishers Ltd, Oxford.

MCNEILL W. H. 1993. Patterns of disease emergence in history. In S. S. Morse (ed.), Emerging viruses: 10-36. 
TORRONI A., BANDELT H.J., MACAULAY V., RICHARDS M., CRUCIANI F., RENGO C., MARTINEZ-CABRERA V., VILLEMS R., KIVISILD T., METSPALU E., PARIK J., TOLK H.V., TAMBETS K., FORSTER P., KARGER B., FRANCALACCI P., RUDAN P., JANICIJEVIC B., RICHARDS O., SAVONTAUS M.-L., HUOPONEN K., LAITINEN V., KOIVUMÄKI S., SYKES B., HICKEY E., NOVELLETTO A., MORAL P., SELLITTO D., COPPA A., AL-
ZAHERI N., SANTACHIARA-BENERECETTI A. S., SEMINO 0. and SCOZZARI R. 2001. A signal, from human mtDNA, of postglacial recolonization in Europe. American Journal of Human Genetics, 69, 844-852.

WOOD J. 1998. A Theroy of Preindustrial Population dynamics. Current Anthropology 39(1): 99-135. 